\title{
RESEARCH
}

Open Access

\section{Clinically-diagnosed vitamin deficiencies and disorders in the entire United States military population, 1997-2015}

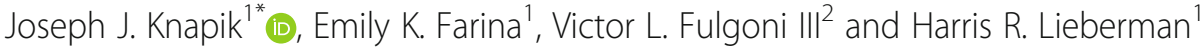

\begin{abstract}
Background: This study examined incidence rates, temporal trends, and demographic factors associated with vitamin deficiencies/disorders in all United States military personnel from 1997 to 2015 (mean N=1,382,266/year).

Methods: Employing an ecological study design, the Defense Medical Epidemiological Database and specific International Classification of Diseases codes were used to determine incidence rates for clinically-diagnosed vitamin deficiencies/disorders. Associations with demographic factors were examined.

Results: The overall incidence rate of vitamin deficiencies/disorders was 92.7 cases/100,000 person-years ( $p$-yr). Highest rates were for vitamin D (53.7 cases/100,000 p-yr), other B-complex vitamins (20.2 cases, 100,000 p-yr), vitamin $B_{12}$ anemia (7.6 cases/100,000 p-yr), deficiencies of "other vitamins" (5.9 cases/100,000 p-yr), and vitamin A (2.5 cases/100,000 p-yr). Thiamin, riboflavin, niacin, pyridoxine, folate, vitamin C, and vitamin K deficiencies and hypervitaminoses A and D had < 1 case/100,000 p-yr. Rates for vitamin D, other B-complex, "other vitamin", and thiamin deficiencies increased over time, while vitamin $A$ and $C$ deficiencies decreased. Women had higher incidence rates for all examined deficiencies/ disorders except niacin and vitamin C. Incidence rates rose with age in 8 of 15 deficiency/disorder categories and blacks had higher incidence rates in 9 of 15 deficiency/disorder categories.

Conclusions: The overall rate of clinically-diagnosed vitamin deficiencies and disorders was low but higher in women and minority subgroups. As for most illnesses, the diagnosed incidence of such disorders may be an underestimate of the actual incidence. These findings can guide clinical decision making with regard to testing for nutritional deficiencies and delivering public health information to at risk populations.
\end{abstract}

Clinical trial registration: (No. ISRCTN58987177). Registration date 9 October 2019.

Keywords: Hypervitaminosis, Hypovitaminosis, Sex, Age, Race, Military service

\footnotetext{
* Correspondence: joseph.j.knapik.civ@mail.mil

'Military Nutrition Division, US Army Research Institute of Environmental

Medicine, 10 General Greene Ave, Natick, MA 01760, USA

Full list of author information is available at the end of the article
}

(c) The Author(s). 2021 Open Access This article is licensed under a Creative Commons Attribution 4.0 International License, which permits use, sharing, adaptation, distribution and reproduction in any medium or format, as long as you give appropriate credit to the original author(s) and the source, provide a link to the Creative Commons licence, and indicate if changes were made. The images or other third party material in this article are included in the article's Creative Commons licence, unless indicated otherwise in a credit line to the material. If material is not included in the article's Creative Commons licence and your intended use is not permitted by statutory regulation or exceeds the permitted use, you will need to obtain permission directly from the copyright holder. To view a copy of this licence, visit http://creativecommons.org/licenses/by/4.0/ The Creative Commons Public Domain Dedication waiver (http://creativecommons.org/publicdomain/zero/1.0/) applies to the data made available in this article, unless otherwise stated in a credit line to the data. 


\section{Background}

Information from medical records on the incidence of clinically-diagnosed dietary deficiencies and hypervitaminoses in a representative sample of the United States (US) population is not available. Nutritional deficiencies are of special interest to the armed forces since they have occurred in various military organizations throughout history, compromising the health and operational effectiveness of service members (SMs). For example, in the 18th and 19th centuries, many sailors in the British Royal Navy were disabled by scurvy until it was discovered the disease was caused by a diet lacking fresh fruits and vegetables, thereby resulting in ships being provisioned with these foods [1]. Many years later, vitamin C deficiency was found to be the underlying cause of the disease [2]. During the US Civil War, a lack of appreciation that vitamin A deficiency resulted in night blindness caused many physicians to ascribe this medical condition to malingering [3]. With improved knowledge of the importance of nutrition, enrichment of certain foods, and dramatic increases in living standards, diseases resulting from nutritional deficiencies or excess and other nutrition-related maladies have been greatly reduced in civilian and military populations in developed countries, but can still be present, and affect health and performance [4-7].

The most common vitamin deficiencies in the US are those associated with vitamin $\mathrm{D}$ and vitamin $\mathrm{B}_{12}$. Vitamin $\mathrm{D}$ is essential for maintaining bone health and performs other important metabolic functions [7-10]. The incidences of vitamin D deficiency were 24 and $54 \%$ in healthy adolescents and community dwelling elderly homebound individuals, respectively [11, 12]. Lower levels of $25(\mathrm{OH}) \mathrm{D}$ have been found to be associated with increased risk of stress fractures in a number of military investigations [13] and Special Operations soldiers have reduced dietary quality, including reduced vitamin D intake when deployed [14]. Vitamin $B_{12}$ is essential for the synthesis of DNA, blood formation, and brain and nerve health $[15,16]$; deficiency can lead to hematological, neuropsychiatric, and cardiovascular disorders [17]. Based on data from the 1999 to $2002 \mathrm{Na}$ tional Health and Nutrition Examination Survey (NHANES), $3-6 \%$ of Americans were $B_{12}$ deficient while $14-20 \%$ had marginal $B_{12}$ depletion [18]. $B_{12}$ deficiency increases with age [18] and can be especially high among adult vegetarian and vegans where deficiency prevalences ranging from $32-90 \%$, have been reported [19]. Other data [20] indicate that prescriptions filled by military SMs for vitamin C and D have risen over a recent 10 -year period suggesting military medical care providers believe that supplementation with certain vitamins is essential to maintain the optimal health of SMs.
We are not aware of any studies that have used medical records to assess the incidence of vitamin deficiencies in any civilian or military population, although the NHANES does provide detailed information on various biomarkers of nutritional status in a representative sample of the US population [21]. The US Department of Defense maintains an epidemiological database that contains all medical encounters of SMs, the International Classification of Diseases Ninth Revision (ICD-9) diagnosis codes associated with each encounter, and basic demographic data. By using these data, the incidence of specific diagnosed vitamin deficiencies can be determined for the total diverse population of SMs, consisting of over 1 million individuals. Military populations may be more susceptible to vitamin deficiencies and disorders due to their frequent deployment to harsh environments, high levels of physical activity, and limited availability of fresh food in some situations. Therefore, this study examined incidence rates, temporal trends, and demographic factors associated with vitamin deficiencies/disorders in all US military personnel. We hypothesized that these factors would differ depending on the vitamins examined.

\section{Methods}

The US Army Research Institute of Environmental Medicine Human Research Protection Office approved this ecological (population-based) study of de-identified data from the Defense Medical Epidemiological Database (DMED). The DMED is an online database that contains inpatient and outpatient medical encounters of all uniformed military personnel (Army, Navy, Marine Corps, and Air Force). The data in the DMED include ICD-9 codes that medical care providers enter into the system after they have assessed the patient during the encounter and determined a diagnosis. By using the DMED, the number of any single medical diagnosis per year in the military population can be determined based on ICD-9 codes. The incidence rates of these medical diagnoses can be calculated since the DMED provides the number of uniformed personnel serving per year. Incidence data can be grouped by a limited number of demographic categories including sex, age, race, and military service.

Participants included the entire population of active duty military personnel serving between 1997 and 2015 . This included SMs in the Army, Navy, Air Force, and Marine Corps. ICD-9 codes used to determine each vitamin deficiency/disorder are shown in Table 1. The number of first occurrences and primary diagnosis in each individual ICD-9 code were obtained by each year, 1997 through 2015, and added together for each category shown in Table 1. Cases involving outpatient visits and hospitalizations (which rarely occurred for these indications) were included and compiled separately. The 
Table 1 ICD-9 Codes for Vitamin Deficiencies \& Disorders

\begin{tabular}{|c|c|c|}
\hline Deficiency/Disorder & Specific Nutritional Problems Included in Category (ICD-9 code description) & ICD-9 Code \\
\hline \multirow[t]{2}{*}{ Thiamine $\left(\mathrm{B}_{1}\right)$ Deficiency } & Beriberi & 265.0 \\
\hline & Other and Unspecified Thiamine Deficiency & 265.1 \\
\hline Riboflavin $\left(B_{2}\right)$ Deficiency & Ariboflavinosis & 266.0 \\
\hline Niacin $\left(B_{3}\right)$ Deficiency & Pellagra & 265.2 \\
\hline Pyridoxine $\left(\mathrm{B}_{6}\right)$ Deficiency & Vitamin $B_{6}$ Deficiency & 266.1 \\
\hline Folate $\left(B_{9}\right)$ Deficiency & Folate Deficiency Anemia & 281.2 \\
\hline \multirow[t]{2}{*}{ Vitamin $B_{12}$ Deficiency } & Pernicious Anemia (Vitamin $B_{12}$ Malabsorption) & 281.0 \\
\hline & "Other Vitamin $B_{12}$ " Deficiency Anemia & 281.1 \\
\hline Folate \& Vitamin $B_{12}$ Deficiency & Other Megaloblastic Anemias & 281.3 \\
\hline \multirow[t]{2}{*}{ Other B-Complex Deficiencies } & Other B-Complex Deficiencies & 266.2 \\
\hline & Unspecified B-Complex Deficiencies & 266.9 \\
\hline \multirow[t]{11}{*}{ Vitamin A Deficiency } & Vitamin A Deficiency with Conjunctival Xerosis & 264.0 \\
\hline & Vitamin A Deficiency with Conjunctival Xerosis \& Bitot's Spot & 264.1 \\
\hline & Vitamin A Deficiency with Corneal Xerosis & 264.2 \\
\hline & Vitamin A Deficiency with Corneal Ulceration and Xerosis & 264.3 \\
\hline & Vitamin A Deficiency with Keratomalacia & 264.4 \\
\hline & Vitamin A Deficiency with Night Blindness & 264.5 \\
\hline & Vitamin A Deficiency with Xerophthalmic Scars of Cornea & 264.6 \\
\hline & Vitamin A Deficiency with Other Ocular Manifestations & 264.7 \\
\hline & Vitamin A Deficiency, Other Manifestations & 264.8 \\
\hline & Vitamin A Deficiency Unspecified & 264.9 \\
\hline & Conjunctival Xerosis Due to Vitamin A Deficiency & 372.53 \\
\hline Vitamin C Deficiency & Ascorbic Acid Deficiency & 267 \\
\hline \multirow[t]{4}{*}{ Vitamin D Deficiency } & Rickets, Active & 268.0 \\
\hline & Rickets, Late Effects & 268.1 \\
\hline & Osteomalacia, Unspecified & 268.2 \\
\hline & Unspecified Vitamin D Deficiency & 268.9 \\
\hline Vitamin K Deficiency & Vitamin K Deficiency & 269.0 \\
\hline \multirow[t]{2}{*}{ Deficiency of "Other Vitamin" } & Deficiency of "Other Vitamins" & 269.1 \\
\hline & Unspecified Vitamin Deficiency & 269.2 \\
\hline \multirow[t]{2}{*}{ Excess Vitamin A (Hypervitaminosis A) } & Hypervitaminosis A & 278.2 \\
\hline & Hypercarotinemia & 278.3 \\
\hline Excess Vitamin D (Hypervitaminosis D) & Hypervitaminosis D & 278.4 \\
\hline
\end{tabular}

incidence rate was calculated as the number of SMs with the first incidence of a particular category (grouping) of ICD-9 codes (or individual code in some cases) divided by the population for that year and multiplied by 100 , 000 (cases/100,000 person-yr [p-yr]). Incidence rate data for the entire cohort were plotted by year.

Cases were also complied by sex, age $(<20,20-24$, $25-29,30-34,35-39, \geq 40$ years), race (white, black, others), and military service (Army, Navy, Air Force, Marine Corps) with the corresponding population. Populations $(\mathrm{N})$ in each demographic strata were obtained by year from the DMED and descriptive statistics for the entire survey period calculated using the Statistical Package for the Social Sciences (SPSS, Version 26). The incidence rate (cases/100,000 p-yr) for each vitamin deficiency/disorder was calculated for each demographic stratum in each category. A referent stratum for each demographic variable (indicated by an incidence rate ratio $=1.00)$ was selected and comparisons were made to that stratum. The Open Source Epidemiologic Calculator was used to determine incidence rate ratios with their 95\% confidence intervals [22]. Only univariable analyses by demographic characteristic and vitamin deficiency/disorder were conducted. Multivariable analyses 
Table 2 Demographics of Service Member Population, 1997-2015

\begin{tabular}{|c|c|c|c|}
\hline Demographic Variable & Strata & $N($ mean $\pm \mathrm{SD})$ & Proportion of Demographic Variable (\%) \\
\hline Total Population & & $1,382,266 \pm 30,987$ & 100.0 \\
\hline \multirow[t]{2}{*}{ Sex } & Men & $1,181,011 \pm 29,728$ & 85.4 \\
\hline & Women & $201,255 \pm 5378$ & 14.6 \\
\hline \multirow[t]{6}{*}{ Age Group } & $<20 y r$ & $102,003 \pm 16,856$ & 7.4 \\
\hline & $20-24 \mathrm{yr}$ & $447,211 \pm 23,715$ & 32.4 \\
\hline & $25-29 y r$ & $305,918 \pm 27,547$ & 22.1 \\
\hline & $30-34 \mathrm{yr}$ & $210,145 \pm 13,502$ & 15.2 \\
\hline & $35-40 y r$ & $174,833 \pm 18,642$ & 12.6 \\
\hline & $>40 \mathrm{yr}$ & $142,156 \pm 7758$ & 10.3 \\
\hline \multirow[t]{3}{*}{ Race } & White & $945,680 \pm 28,412$ & 68.4 \\
\hline & Black & $250,526 \pm 19,488$ & 18.1 \\
\hline & Other & $186,060 \pm 8247$ & 13.5 \\
\hline \multirow[t]{4}{*}{ Military Service } & Army & $506,209 \pm 31,422$ & 36.6 \\
\hline & Navy & $348,099 \pm 25,871$ & 25.2 \\
\hline & Air Force & $344,083 \pm 19,850$ & 24.9 \\
\hline & Marine Corps & $183,875 \pm 11,663$ & 13.3 \\
\hline
\end{tabular}

Table 3 Overall Cases and Incidence Rates for Nutritional Deficiencies and Disorders in US Military Personnel, 1997-2015

\begin{tabular}{|c|c|c|c|c|c|c|}
\hline \multirow{2}{*}{$\begin{array}{l}\text { Nutritional Deficiency/ } \\
\text { Disorder }\end{array}$} & \multicolumn{2}{|c|}{ Outpatient } & \multicolumn{2}{|c|}{ Inpatient } & \multicolumn{2}{|l|}{ Total } \\
\hline & $\begin{array}{l}\text { Cases } \\
(n)\end{array}$ & $\begin{array}{l}\text { Incidence Rate (cases/100, } \\
000 \text { person-yr) }\end{array}$ & $\begin{array}{l}\text { Cases } \\
(n)\end{array}$ & $\begin{array}{l}\text { Incidence Rate (cases/100, } \\
000 \text { person-yr) }\end{array}$ & $\begin{array}{l}\text { Cases } \\
(n)\end{array}$ & $\begin{array}{l}\text { Incidence Rate (cases/100, } \\
000 \text { person-yr) }\end{array}$ \\
\hline $\begin{array}{l}\text { Thiamine }\left(\mathrm{B}_{1}\right) \text { Deficiency } \\
\text { (Beriberi \& Other) }\end{array}$ & 209 & 0.80 & 12 & 0.05 & 221 & 0.84 \\
\hline $\begin{array}{l}\text { Riboflavin ( } B_{2} \text { ) Deficiency } \\
\text { (Ariboflavinosis) }\end{array}$ & 32 & 0.12 & 0 & 0.00 & 32 & 0.12 \\
\hline $\begin{array}{l}\text { Niacin }\left(B_{3}\right) \text { Deficiency } \\
\text { (Pellagra) }\end{array}$ & 51 & 0.19 & 0 & 0.00 & 51 & 0.19 \\
\hline Pyridoxine $\left(B_{6}\right)$ Deficiency & 61 & 0.23 & 0 & 0.00 & 61 & 0.23 \\
\hline Folate $\left(B_{9}\right)$ Anemia & 178 & 0.68 & 1 & 0.00 & 179 & 0.68 \\
\hline Vitamin $\mathrm{B}_{12}$ Anemia & 1984 & 7.55 & 16 & 0.06 & 2000 & 7.62 \\
\hline $\begin{array}{l}\text { Folate and Vitamin } \mathrm{B}_{12} \\
\text { Anemia }\end{array}$ & 60 & 0.23 & 2 & 0.01 & 62 & 0.24 \\
\hline $\begin{array}{l}\text { Other B-Complex } \\
\text { Deficiencies }\end{array}$ & 5303 & 20.19 & 13 & 0.05 & 5316 & 20.24 \\
\hline Vitamin A Deficiency & 659 & 2.51 & 0 & 0.00 & 659 & 2.51 \\
\hline Vitamin C Deficiency & 52 & 0.20 & 1 & 0.00 & 53 & 0.20 \\
\hline Vitamin D Deficiency & 14,102 & 53.70 & 11 & 0.04 & 14,113 & 53.73 \\
\hline Vitamin K Deficiency & 49 & 0.19 & 0 & 0.00 & 49 & 0.19 \\
\hline $\begin{array}{l}\text { Deficiency of "Other } \\
\text { Vitamins" }\end{array}$ & 1559 & 5.94 & 1 & 0.00 & 1560 & 5.94 \\
\hline Hypervitaminosis A & 68 & 0.26 & 0 & 0.00 & 68 & 0.26 \\
\hline Hypervitaminosis D & 33 & 0.13 & 0 & 0.00 & 33 & 0.13 \\
\hline
\end{tabular}


were not possible since the DMED only provides data grouped by demographics and does not provide individual data.

\section{Results}

Table 2 shows the demographics of the SM population for the entire period from 1997 through 2015. Table 2 represents averages and standards deviations for all years complied. The population was predominately white men aged 20 to 29 years, although other demographics were also represented. For example, there are over 200,000 women and over 250,000 black SMs.

Table 3 presents the overall number of cases and incidence rates of each vitamin deficiency and disorder for the entire period. The overall incidence rate of vitamin deficiencies (13 categories) was 92.7 cases/100,000 p-yr and the overall incidence rate for the two hypervitaminosis categories was 0.4 cases/100,000 p-yr. The highest
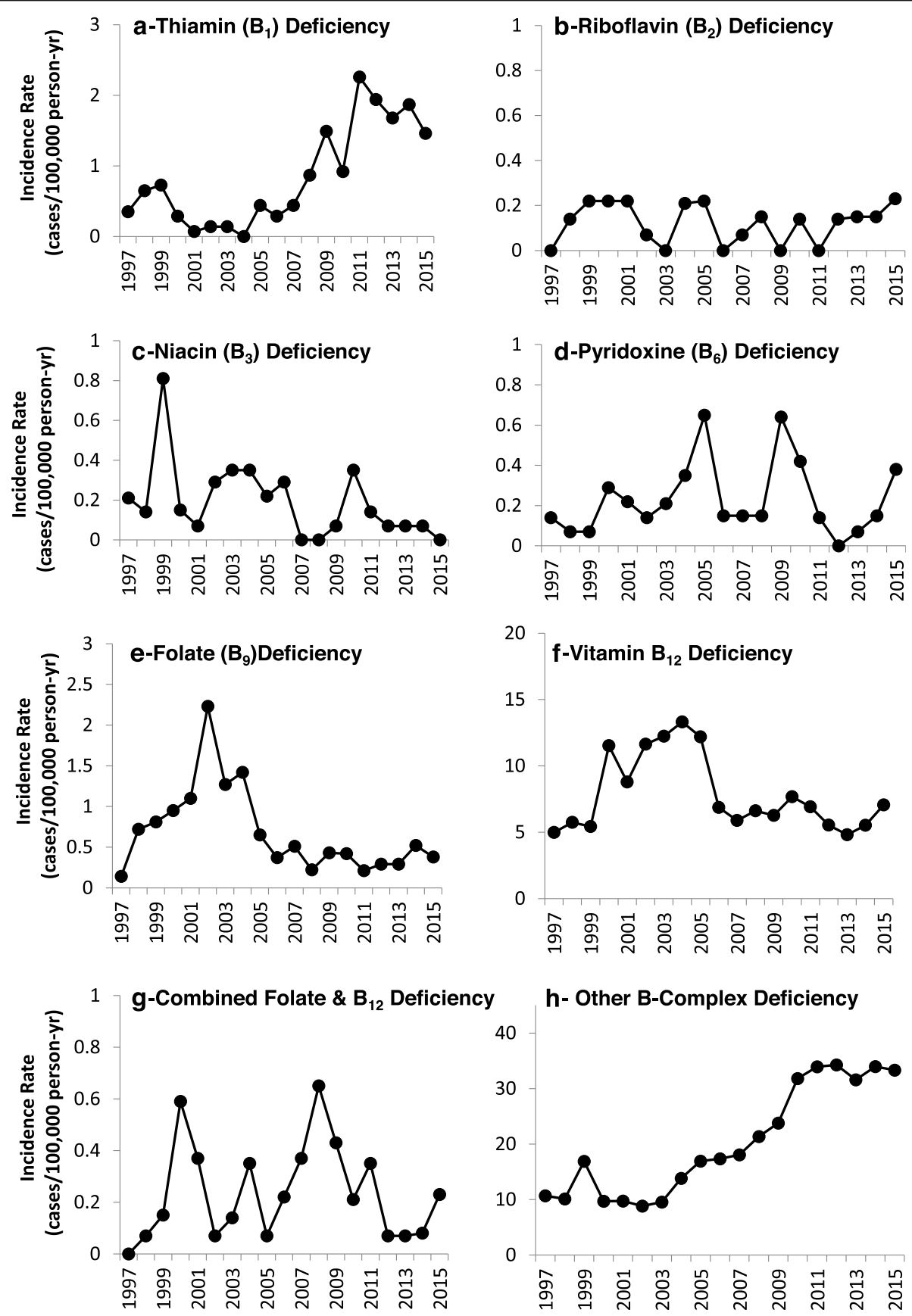

Fig. 1 Incidence Rate of Clinically-Diagnosed Vitamin Deficiencies and Disorder in US Military Service Members, 1997-2015 
overall rate for a single deficiency was for vitamin D, followed by (in order of decreasing rates) other Bcomplex deficiency, vitamin $\mathrm{B}_{12}$ anemia, deficiencies of "other vitamins", and vitamin A deficiency. All other deficiencies and disorders had $<1$ case/100,000 p-yr. There were very few cases involving hospitalizations (inpatient cases), accounting for only $0.2 \%(n=57)$ of the vitamin deficiencies/disorder cases.

Figure 1 presents secular trends in incidence rates for B-vitamin deficiencies. The vertical axes differ for each vitamin so the temporal trends can be easily visualized. There was little change over years for riboflavin, niacin, pyridoxine, and combined folate and $\mathrm{B}_{12}$ deficiencies. Individually, incidence rates for folate and $B_{12}$ deficiencies rose in early years but returned to lower levels later. Thiamine and other B-complex deficiencies were higher in later years. Fig. 2 presents the secular trends in incidence rates for other vitamin deficiencies and the hypervitaminoses. There was little change in rates for vitamin $\mathrm{K}$ deficiency and hypervitaminosis A. Vitamin A and
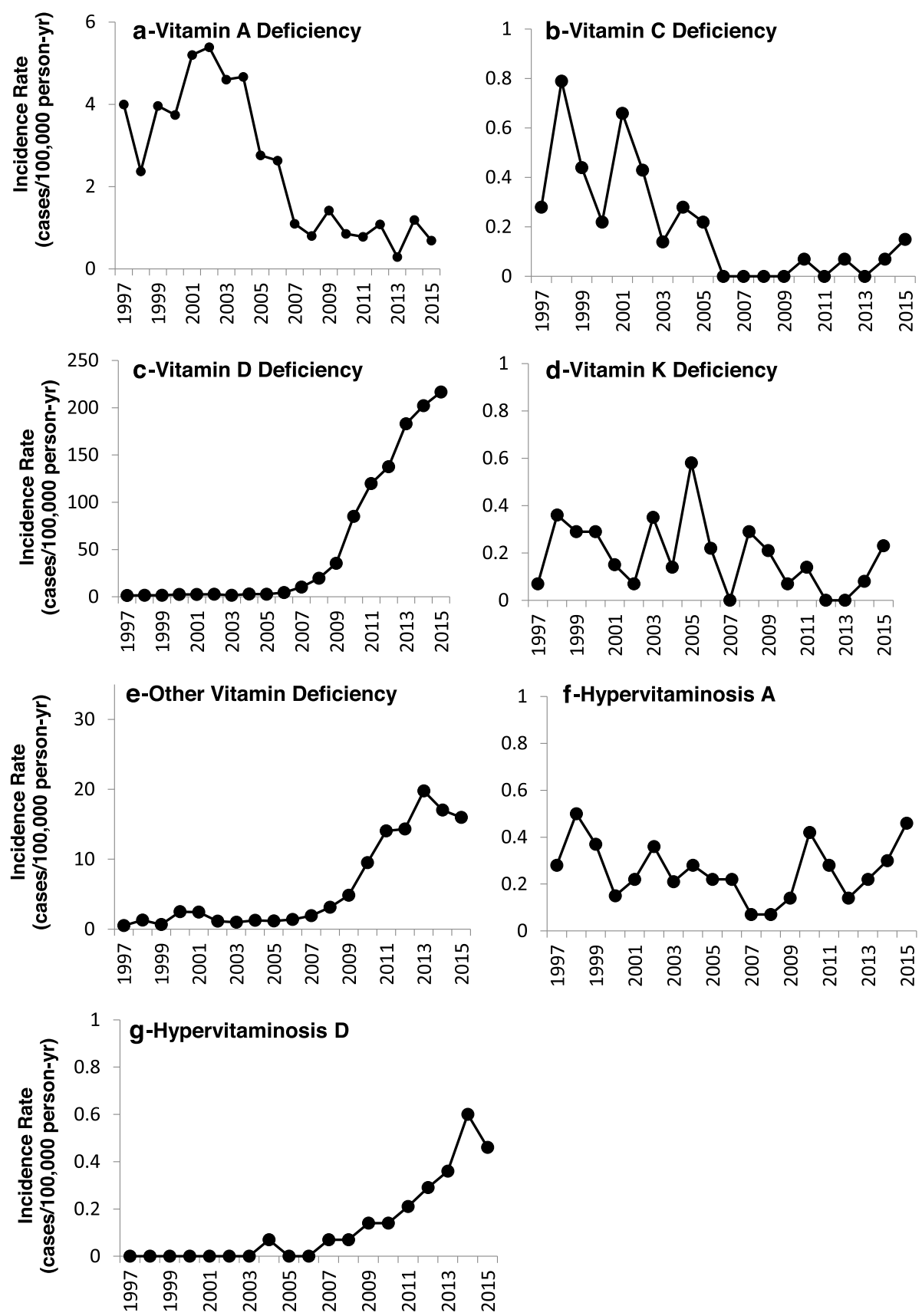

Fig. 2 Incidence Rate of Clinically-Diagnosed Vitamin Deficiencies and Disorder in US Military Service Members, 1997-2015 
Table 4 Univariable Analysis of Vitamin Deficiencies and Disorders among United States Military Personnel by Demographic Characteristics (1997-2015)

\begin{tabular}{|c|c|c|c|c|c|c|c|c|c|c|c|}
\hline $\begin{array}{l}\text { Deficiency/ } \\
\text { Disorder }\end{array}$ & Variable & Strata & $N$ & $\begin{array}{l}\text { Incidence } \\
\text { Rate (cases/ } \\
100,000 \\
\text { person-yr) }\end{array}$ & $\begin{array}{l}\text { Incidence Rate } \\
\text { Ratio }(95 \% \\
\text { Confidence } \\
\text { Interval) }\end{array}$ & $\begin{array}{l}\text { Deficiency/ } \\
\text { Disorder }\end{array}$ & Variable & Strata & $N$ & $\begin{array}{l}\text { Incidence } \\
\text { Rate (cases/ } \\
100,000 \\
\text { person-yr) }\end{array}$ & $\begin{array}{l}\text { Incidence Rate } \\
\text { Ratio }(95 \% \\
\text { Confidence } \\
\text { Interval) } \\
\end{array}$ \\
\hline \multirow{15}{*}{$\begin{array}{l}\text { Thiamine } \\
\left(\mathrm{B}_{1}\right) \\
\text { Deficiency }\end{array}$} & \multirow[t]{2}{*}{ Sex } & Male & 161 & 0.27 & 1.00 & \multirow{15}{*}{$\begin{array}{l}\text { Riboflavin } \\
\left(B_{2}\right) \\
\text { Deficiency }\end{array}$} & \multirow[t]{2}{*}{ Sex } & Male & 19 & 0.08 & 1.00 \\
\hline & & Female & 60 & 1.57 & $2.19(1.63-2.94)$ & & & Female & 13 & 0.34 & $4.05(1.98-8.13)$ \\
\hline & \multirow[t]{6}{*}{ Age } & $<20$ & 6 & 0.31 & 1.00 & & \multirow[t]{6}{*}{ Age } & $<20$ & 3 & 0.15 & 1.00 \\
\hline & & $20-24$ & 43 & 0.51 & $1.63(0.70-3.84)$ & & & $20-24$ & 6 & 0.07 & $0.46(0.11-1.82)$ \\
\hline & & $25-29$ & 34 & 0.58 & $1.88(0.79-4.50)$ & & & $25-29$ & 2 & 0.03 & $0.22(0.04-1.33)$ \\
\hline & & $30-34$ & 48 & 1.20 & $3.88(1.66-9.07)$ & & & $30-34$ & 6 & 0.15 & $0.97(0.24-3.88)$ \\
\hline & & $35-39$ & 36 & 1.08 & $3.50(1.48-8.31)$ & & & $35-39$ & 5 & 0.15 & $0.97(0.23-4.07)$ \\
\hline & & $\geq 40$ & 54 & 2.00 & $6.46(2.78-15.01)$ & & & $\geq 40$ & 10 & 0.37 & $2.39(0.66-8.69)$ \\
\hline & \multirow[t]{3}{*}{ Race } & White & 124 & 0.69 & 1.00 & & \multirow[t]{3}{*}{ Race } & White & 16 & 0.09 & 1.00 \\
\hline & & Black & 75 & 1.58 & $2.28(1.71-3.04)$ & & & Black & 11 & 0.23 & $2.60(1.20-5.59)$ \\
\hline & & Other & 22 & 0.62 & $0.90(0.57-1.42)$ & & & Other & 5 & 0.14 & $1.59(0.58-4.34)$ \\
\hline & \multirow[t]{4}{*}{ Service } & Army & 102 & 1.06 & 1.00 & & \multirow[t]{4}{*}{ Service } & Army & 20 & 0.21 & 1.00 \\
\hline & & Navy & 42 & 0.64 & $0.60(0.42-0.86)$ & & & Navy & 2 & 0.03 & $0.14(0.03-0.62)$ \\
\hline & & $\begin{array}{l}\text { Air } \\
\text { Force }\end{array}$ & 62 & 0.95 & $0.89(0.65-1.23)$ & & & $\begin{array}{l}\text { Air } \\
\text { Force }\end{array}$ & 7 & 0.11 & $0.51(0.22-1.22)$ \\
\hline & & Marines & 15 & 0.43 & $0.40(0.24-0.70)$ & & & Marines & 3 & 0.09 & $0.41(0.13-1.39)$ \\
\hline \multirow{15}{*}{$\begin{array}{l}\text { Niacin }\left(B_{3}\right) \\
\text { Deficiency }\end{array}$} & \multirow[t]{2}{*}{ Sex } & Male & 46 & 0.21 & 1.00 & \multirow{15}{*}{$\begin{array}{l}\text { Pyridoxine } \\
\left(\mathrm{B}_{6}\right) \\
\text { Deficiency }\end{array}$} & \multirow[t]{2}{*}{ Sex } & Male & 40 & 0.18 & 1.00 \\
\hline & & Female & 5 & 0.13 & $0.64(0.25-1.61)$ & & & Female & 21 & 0.55 & $3.08(1.82-5.22)$ \\
\hline & \multirow[t]{6}{*}{ Age } & $<20$ & 1 & 0.05 & 1.00 & & \multirow[t]{6}{*}{ Age } & $<20$ & 0 & 0.00 & - \\
\hline & & $20-24$ & 8 & 0.09 & $1.83(0.23-14.59)$ & & & $20-24$ & 12 & 0.14 & 1.00 \\
\hline & & $25-29$ & 11 & 0.19 & $3.67(0.47-28.41)$ & & & $25-29$ & 8 & 0.14 & $0.97(0.40-2.38)$ \\
\hline & & $30-34$ & 9 & 0.23 & $4.37(0.55-34.48)$ & & & $30-34$ & 9 & 0.23 & $1.60(0.67-3.79)$ \\
\hline & & $35-39$ & 8 & 0.24 & $4.67(0.58-37.31)$ & & & $35-39$ & 13 & 0.39 & $2.77(1.27-6.07)$ \\
\hline & & $\geq 40$ & 14 & 0.52 & $\begin{array}{l}10.05(1.32- \\
76.38)\end{array}$ & & & $\geq 40$ & 19 & 0.70 & $4.98(2.42-10.26)$ \\
\hline & \multirow[t]{3}{*}{ Race } & White & 36 & 0.20 & 1.00 & & \multirow[t]{3}{*}{ Race } & White & 33 & 0.18 & 1.00 \\
\hline & & Black & 9 & 0.19 & $0.94(0.45-1.96)$ & & & Black & 21 & 0.44 & $2.40(1.39-4.15)$ \\
\hline & & Other & 6 & 0.17 & $0.85(0.36-2.01)$ & & & Other & 7 & 0.20 & $1.08(0.48-2.44)$ \\
\hline & \multirow[t]{4}{*}{ Service } & Army & 14 & 0.15 & 1.00 & & \multirow[t]{4}{*}{ Service } & Army & 31 & 0.32 & 1.00 \\
\hline & & Navy & 10 & 0.15 & $1.03(0.46-2.34)$ & & & Navy & 8 & 0.12 & $0.38(0.17-0.82)$ \\
\hline & & $\begin{array}{l}\text { Air } \\
\text { Force }\end{array}$ & 22 & 0.34 & $2.31(1.18-4.52)$ & & & $\begin{array}{l}\text { Air } \\
\text { Force }\end{array}$ & 16 & 0.24 & $0.76(0.42-1.39)$ \\
\hline & & Marines & 5 & 0.14 & $0.98(0.35-2.73)$ & & & Marines & 6 & 0.17 & $0.53(0.22-1.28)$ \\
\hline \multirow{9}{*}{$\begin{array}{l}\text { Folate }\left(B_{g}\right) \\
\text { Deficiency } \\
\text { Anemia }\end{array}$} & \multirow[t]{2}{*}{ Sex } & Male & 80 & 0.36 & 1.00 & \multirow{9}{*}{$\begin{array}{l}\text { Vitamin } B_{12} \\
\text { Anemia }\end{array}$} & Sex & Male & 1147 & 5.11 & 1.00 \\
\hline & & Female & 99 & 2.59 & $7.26(5.41-9.75)$ & & & Female & 853 & 22.31 & $4.36(3.99-4.77)$ \\
\hline & Age & $<20$ & 20 & 1.03 & 1.00 & & Age & $<20$ & 59 & 3.04 & 1.00 \\
\hline & & $20-24$ & 46 & 0.54 & $0.52(0.31-0.89)$ & & & $20-24$ & 275 & 3.24 & $1.06(0.80-1.41)$ \\
\hline & & $25-29$ & 28 & 0.48 & $0.47(0.26-0.83)$ & & & $25-29$ & 276 & 4.75 & $1.56(1.18-2.07)$ \\
\hline & & $30-34$ & 18 & 0.45 & $0.43(0.23-0.83)$ & & & $30-34$ & 297 & 7.44 & $2.44(1.85-3.23)$ \\
\hline & & $35-39$ & 29 & 0.87 & $0.85(0.48-1.50)$ & & & $35-39$ & 420 & 12.64 & $4.15(3.16-5.45)$ \\
\hline & & $\geq 40$ & 38 & 1.41 & $1.36(0.79-2.34)$ & & & $\geq 40$ & 673 & 24.92 & $8.19(6.27-10.68)$ \\
\hline & Race & White & 92 & 0.51 & 1.00 & & Race & White & 1144 & 6.37 & 1.00 \\
\hline
\end{tabular}


Table 4 Univariable Analysis of Vitamin Deficiencies and Disorders among United States Military Personnel by Demographic Characteristics (1997-2015) (Continued)

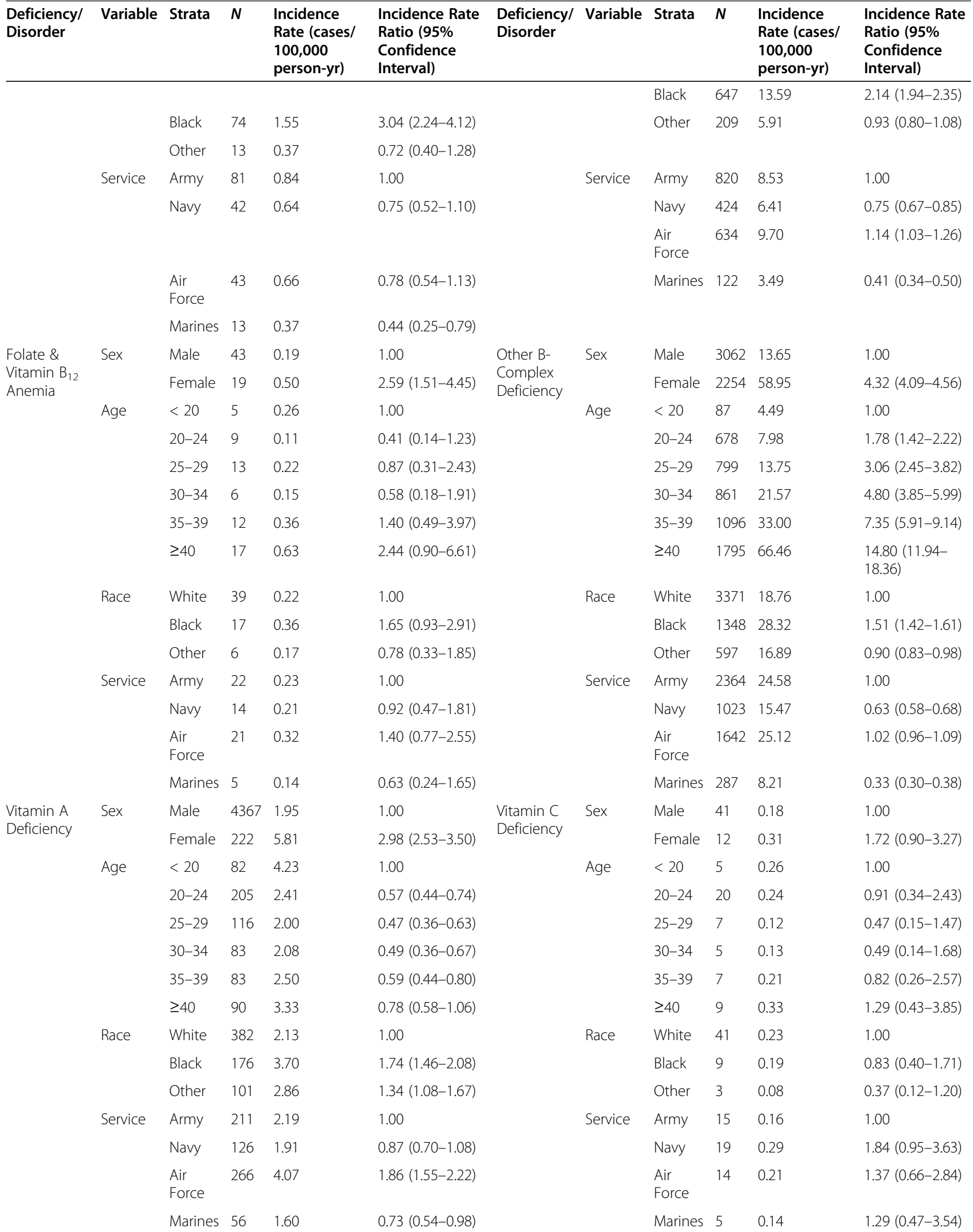


Table 4 Univariable Analysis of Vitamin Deficiencies and Disorders among United States Military Personnel by Demographic Characteristics (1997-2015) (Continued)

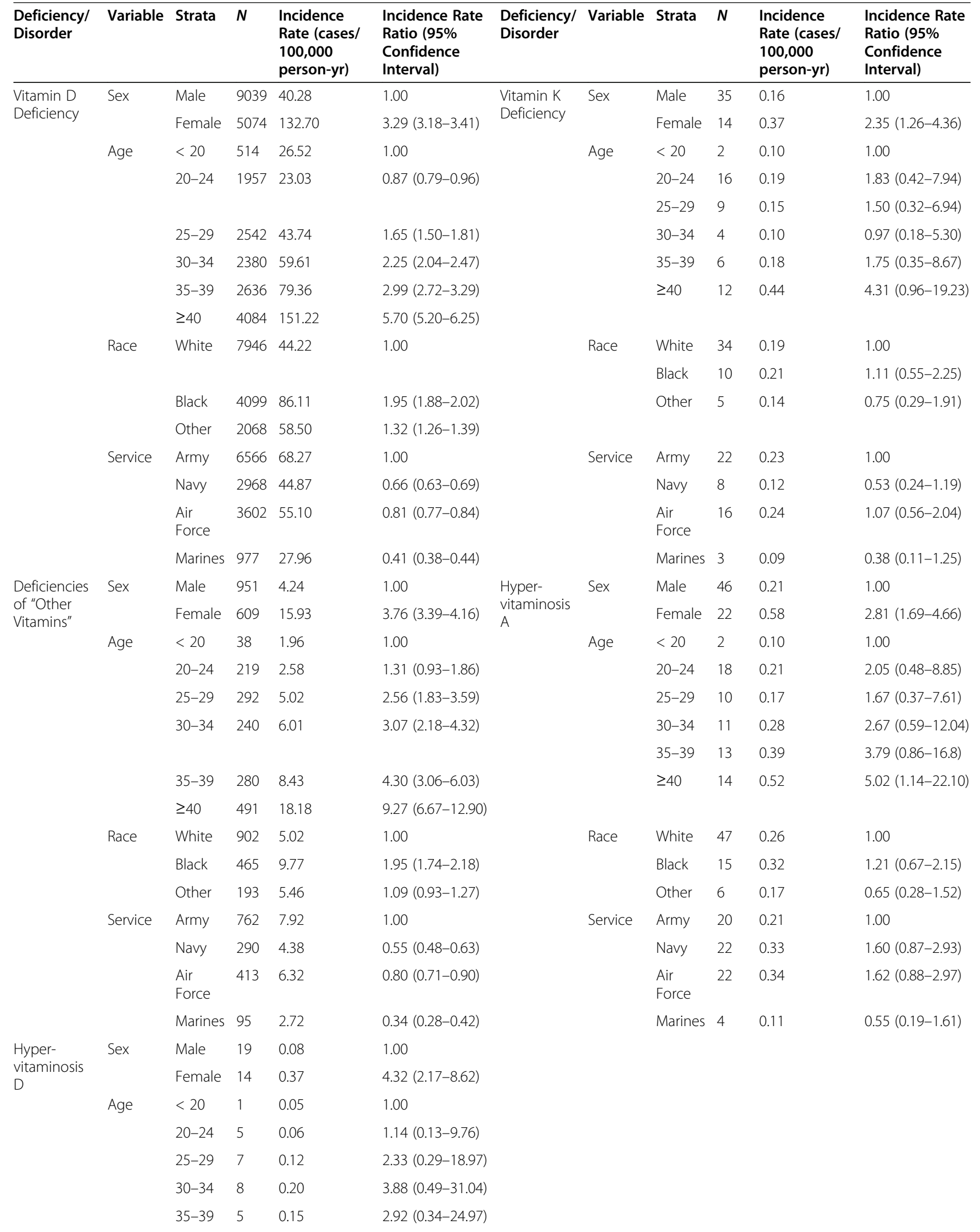


Table 4 Univariable Analysis of Vitamin Deficiencies and Disorders among United States Military Personnel by Demographic Characteristics (1997-2015) (Continued)

\begin{tabular}{|c|c|c|c|c|c|c|c|c|c|c|}
\hline $\begin{array}{l}\text { Deficiency/ } \\
\text { Disorder }\end{array}$ & Variable & Strata & $N$ & $\begin{array}{l}\text { Incidence } \\
\text { Rate (cases/ } \\
100,000 \\
\text { person-yr) }\end{array}$ & $\begin{array}{l}\text { Incidence Rate } \\
\text { Ratio ( } 95 \% \\
\text { Confidence } \\
\text { Interval) }\end{array}$ & $\begin{array}{l}\text { Deficiency/ Variable } \\
\text { Disorder }\end{array}$ & Strata & $N$ & $\begin{array}{l}\text { Incidence } \\
\text { Rate (cases/ } \\
100,000 \\
\text { person-yr) }\end{array}$ & $\begin{array}{l}\text { Incidence Rate } \\
\text { Ratio ( } 95 \% \\
\text { Confidence } \\
\text { Interval) }\end{array}$ \\
\hline & & $\geq 40$ & 7 & 0.26 & $5.02(0.62-40.82)$ & & & & & \\
\hline & \multirow[t]{3}{*}{ Race } & White & 24 & 0.13 & 1.00 & & & & & \\
\hline & & Black & 9 & 0.19 & $1.42(0.66-3.05)$ & & & & & \\
\hline & & Other & 0 & 0.00 & - & & & & & \\
\hline & \multirow[t]{4}{*}{ Service } & Army & 16 & 0.17 & 1.00 & & & & & \\
\hline & & Navy & 5 & 0.08 & $0.45(0.17-1.24)$ & & & & & \\
\hline & & $\begin{array}{l}\text { Air } \\
\text { Force }\end{array}$ & 11 & 0.17 & $1.01(0.47-2.18)$ & & & & & \\
\hline & & Marines & 1 & 0.03 & $0.17(0.02-1.30)$ & & & & & \\
\hline
\end{tabular}

vitamin $\mathrm{C}$ deficiency incidence rates declined over time. Vitamin D deficiency, "other vitamin" deficiency, and hypervitaminosis D incidence rates rose in later years. Vitamin D deficiency rates ranged from 1.5 to 4.6 cases/100, 000 p-yr between 1997 and 2006.

Table 4 presents vitamin deficiencies and disorders by demographic characteristics. Incidence rates for thiamin deficiency were higher among women, blacks, and Army personnel (compared to the Navy and Marines), and generally increased with age. Riboflavin deficiency rates were higher among women, blacks, Army personnel (compared to the Navy), and the oldest age group. Niacin deficiency increased with age and was highest in the Air Force. Pyridoxine deficiency rates were higher among women, older age groups, blacks, and Army personnel (compared to the Navy). Folate deficiency incidence rates were higher among women, the youngest age group (compared to the 20-34 year olds), blacks, and the Army (compared to the Marines). Vitamin $B_{12}$ anemia incidence rates were higher among women, increased with age, were higher among blacks, and were lower in the Navy and Marines, but higher in the Air Force compared to Army. Combined folate and $\mathrm{B}_{12}$ deficiency anemia rate was higher among women, but did not differ significantly by age, race, or service. Other Bcomplex deficiency incidence rates were higher among women, increased substantially with age, and were higher among blacks, but lower in other races (compared to whites), and higher in Army personnel compared to Navy and Marine personnel.

Vitamin A deficiency incidence rates were higher among women, the youngest age group (compared to those 20-39 years of age), blacks and other races, and in Air Force personnel, but lower in Marines (compared to the Army). Vitamin C deficiency incidence rates differed little by demographic characteristics. Vitamin D deficiency incidence rates were higher in women, generally increased with age, were higher among blacks and other races, and higher among Army personnel compared to other services. Vitamin K deficiency incidence rates were higher in women, but differed little by other demographics. The incidence rates for deficiencies of "other vitamins" were higher in women, increased with age, were higher for blacks, and were higher in Army personnel compared to the other services. Hypervitaminosis A incidence rates were higher among women and tended to increase with age. Hypervitaminosis D incidence rates were higher among women, but differed little by other demographics.

\section{Discussion}

This study was, to our knowledge, the first examination of incidence rates of clinically-diagnosed vitamin deficiencies and disorders in the entire US military population, or any other US population. The overall rates were low, but the likelihood of a diagnosis of any specific deficiency varied substantially. Rates also varied by demographic characteristics, with women and blacks typically having higher incidences of many deficiencies. These findings can guide clinical decision-making with regard to testing for specific deficiencies in at risk military and similar civilian populations and delivering public health information to specific demographic groups. Although the demographics of the military population varies from the overall US population, it is likely these findings apply to the younger portions of the US civilian population and have similar clinical and public health implications.

One of the most dramatic trends observed was a large increase in the incidence rate for vitamin $\mathrm{D}$ deficiencies beginning about 2007. Prescriptions written by health care providers for vitamin D and filled by SMs increased 55-fold from 2005 to 2013 [20], and prescription fill rates were higher among women, increased with age, and were highest in the Army and lowest in the Marines 
[23], corresponding with the data presented here. In 1997 (the beginning of our survey period), an Institute of Medicine (IOM) report established the adequate intake level for vitamin D at 200 International Units (IU) for adults based on the amount of dietary intake required to achieve a serum level of plasma $25(\mathrm{OH}) \mathrm{D}$ level of about $30 \mathrm{nmols} / \mathrm{l}$ [24]. Subsequently, additional research indicated either the plasma $25(\mathrm{OH}) \mathrm{D}$ levels or the dietary intake of vitamin D of Americans were insufficient $[25,26]$. This was followed by considerable media attention [27-29] and scientific/medical reporting [7, 30, 31]. More accurate methods of measuring $25(\mathrm{OH}) \mathrm{D}$ also became available [32]. In 2011, the IOM concluded $25(\mathrm{OH}) \mathrm{D}$ levels $<30 \mathrm{nmols} / \mathrm{l}$ were associated with reduced calcium absorption and osteomalacia in young and middle aged adults, but there was little evidence of benefits for levels $>50 \mathrm{nmols} / \mathrm{l}$ [33]. To achieve a plasma level of $50 \mathrm{nmols} / \mathrm{l}$, the committee recommended a daily allowance (RDA) of vitamin D of $600 \mathrm{IU} /$ day [33]. The increasing attention devoted to vitamin $\mathrm{D}$ in the popular and medical literature, better availability and more accurate assay procedures, knowledge that large portions of individuals may be vitamin $\mathrm{D}$ deficient, and the change in national policy may account for the increase in vitamin $\mathrm{D}$ deficiency diagnoses during the survey period.

Coincident with the rise in vitamin $\mathrm{D}$ deficiencies was an increase in vitamin D hypervitaminosis. There was $\leq 1$ case/year prior to 2008 with a maximum of 8 cases in 2014 so overall rates were small. As testing for vitamin D deficiency increased, it is not surprising vitamin D hypervitaminosis increased. One population-based study found $1.3 \%$ of individuals tested had $25(\mathrm{OH}) \mathrm{D}$ levels > $125 \mathrm{nmol} / \mathrm{l}$ [34]. Some of the vitamin D hypervitaminosis cases observed in this study could be associated with use of vitamin D dietary supplements since $69 \%$ of SMs use supplements [35] and many contain vitamin D. Vitamin $\mathrm{D}$ has been reported to have ergogenic effects, which may encourage SMs to use vitamin D supplements [5, 36]. Dosages on supplement labels are often inconsistent with actual content which can lead to high/excess intakes in some cases [37].

Other interesting secular trends were the decreases in clinically-diagnosed vitamins $\mathrm{A}$ and $\mathrm{C}$ deficiency over time, although the incidence rates were low overall. Prescriptions filled for vitamin $C$ supplements by SMs increased in the 2005-2013 period [20], possibly accounting for at least a portion of the decline in vitamin $C$ deficiency. In 2000, the RDA of vitamin A was lowered $[38,39]$ and coincident with this was the decline in vitamin A deficiency diagnoses a few years later among SMs. The lower vitamin A RDA and setting of an upper tolerable limit raised some concern about excessive intake [40, 41], but as shown here the incidence rates for hypervitaminosis $\mathrm{A}$ was extremely low and changed little during the survey period in the military population.

The incidence rates for other B-complex vitamins and "other vitamin" deficiencies rose over the survey period. Other B-complex and "other vitamin" deficiencies respectively accounted for $22 \%(5316 / 24,356)$ and $6 \%$ $(1560 / 24,356)$ of the vitamin deficiency cases, respectively. Clinical experience suggests medical care providers use ICD-9 codes associated with these "other" categories when a specific deficiency is not listed within the ICD-9 codes, and also when they cannot determine a specific vitamin that might be associated with a medical problem. If the latter is the case, it may be that the incidence rates for some specific clinically diagnosed vitamin deficiencies may be underestimated, but this cannot be determined with certainty given the data available within the DMED.

Vitamin $B_{12}$ anemia had the third highest incidence rate in this study, increased between 1998 and 2005 and returning to lower levels after 2005. Data from NHAN ES [42] showed little change in serum levels of vitamin $\mathrm{B}_{12}$ from 1988 to 2004 and little difference by sex. Serum levels did decrease with age [42] and lower intake levels or intakes below the RDA were more predominant in older adults and non-Hispanic blacks (compared to non-Hispanic whites) [43, 44], which corresponds with the clinical data in the present study.

Various demographic factors were associated with higher deficiency/disorder rates. Women had higher rates than men in 13 of the 15 deficiency/disorder categories examined. Data from NHANES (2003-2008) indicated women were more likely than men to have insufficient intakes of folate, vitamin $B_{12}$, and vitamin $D$ $[43,45]$. Women may be more likely to be diagnosed with various illnesses since they use more medical care than men [23, 46-48] even after excluding visits for pregnancy $[46,48]$. Age was also associated with vitamin deficiencies/disorders since 9 of 13 vitamin deficiency/ disorder categories (thiamin, niacin, pyridoxine, vitamin $\mathrm{B}_{12}$, other B-complex, vitamin $\mathrm{D}$, "other vitamins", and hypervitaminoses A and D) increased with age. Data from NHANES (2009-2012) showed the proportion of individuals below the Estimated Average Requirement increased with age for many B-vitamins (thiamin, niacin, folate, pyridoxine, $B_{12}$ ) even when dietary supplement intake was included [49], an important factor in military personnel given their high use of dietary supplements compared to civilians [35]. Vitamins C and D did not show the age-related trend [49]. Also, previous studies show that for most major diagnostic categories, ambulatory visits and filling of drug prescriptions are higher among older individuals compared to younger ones [23, 46], evidence of greater health care use with aging. With regard to race, blacks had higher disorder/deficiency 
rates in 10 of 15 categories. Data from NHANES (20092012) indicates a larger proportion of non-Hispanic blacks consumed less than their estimated average requirement for thiamin, riboflavin, niacin, folate, pyridoxine, vitamin $B_{12}$, and vitamin $D$ [44] or had insufficient intakes of many of these vitamins compared to nonHispanic whites [45]. Race may be associated with behaviors that favor certain types of foods or preparation methods that might influence vitamin intake [50-52].

There are limitations that should be considered in interpreting the findings of this study. Medical care provided by medics and at deployed locations may not be included in the DMED, although it is unlikely the nutritional conditions examined in this study would be diagnosed by medics or in the field. Also, our analysis is based on the primary diagnosis of the nutritional condition (first listed condition) in the DMED and thus may not account for comorbidities. The DMED only provides the first case of SM medical problem by ICD-9 code (incidence) or the total number of visits for that medical condition (total encounters). If the nutritional condition (ICD-9 code) was listed in position other than the first (primary) because of a comorbid problem that condition would not be included in the analysis. Thus, this analysis is limited to the nutritional conditions for which the diagnoses were the primary ones. Finally, the rates here are undoubtedly an underestimate of the actual incidence of these deficiencies/disorders in the military population. The data only include cases where SMs presented to a medical care provider and the provider diagnosed the patient as having a specific deficiency/ disorder. It is likely that a number of individuals who had deficiencies did not seek medical attention.

\section{Conclusions}

This study found a low rate of clinically-diagnosed vitamin deficiencies/disorders. Despite this, vitamin D deficiency, deficiency of other B-complex vitamins, and deficiencies of "other vitamins" had increasing incidence rates and are areas of concern that should be under continued surveillance. Women had higher incidence rates for 13 of 15 deficiency/ disorder categories and blacks had higher incidence rates in 10 of 15 categories. While we are unaware of any other population-based data assessment of medical records to assess incidence of diagnosed dietary deficiencies and disorders, given advancement in digitized medical records and the desire to access and use large data sets it is likely that such information could be available in the US population in the near future. As such, our results will be useful to those conducting these future analyses.

\section{Abbreviations}

25(OH)D: 25-hydroxyvitamin D; DMED: Defense Medical Epidemiology Database; ICD-9: International Classification of Diseases, Revision 9;

IOM: Institute of Medicine; IU: International units; NHANES: National Health and Nutrition Examination Survey; p-yr: Person-years; RDA: Recommended daily allowance; SM: Service member; US: United States

\section{Acknowledgements}

Thanks to Ms. Patricia Bremner for library work and the staff of the Armed Forces Health Surveillance Branch of the Defense Health Agency for answering our DMED questions. Permission was obtained from the individual and organization named.

\section{Authors' contributions}

Dr. J J K contributed to study design, compiled the data, analyzed the data, assisted in interpretation, and wrote the paper; Dr. E K F contributed to study design, assisted in interpretation, and critically reviewed drafts of the paper; Dr. V L F III contributed to study design, assisted in interpretation, and critically reviewed drafts of the paper; Dr. H R L conceived the study, contributed to study design, assisted in interpretation, and critically reviewed drafts of the paper. All authors have read and approved the manuscript.

\section{Funding}

Department of Defense Center Alliance for Nutrition and Dietary Supplements Research, Defense Medical Research and Development Program.

Availability of data and materials

Available from authors on reasonable request

\section{Declarations}

Consent to participate

Not applicable; de-identified data and non-human research.

\section{Ethics approval}

The United States Army Research Institute of Environmental Medicine Human Research Protection Office approved this retrospective analysis of deidentified data.

\section{Consent for publication}

US Army Research Institute of Environmental Medicine

\section{Competing interests}

All authors report no conflict of interest in regard to this work.

\section{Author details}

'Military Nutrition Division, US Army Research Institute of Environmental Medicine, 10 General Greene Ave, Natick, MA 01760, USA. Nutrition Impact, LLC, 9725 D Drive North, Battle Creek, Ml 49014, USA.

Received: 4 November 2020 Accepted: 18 May 2021

Published online: 15 June 2021

\section{References}

1. Magiorkinis E, Beloukas A, Diamantis A. Scurvy: past, present, and future. Eur J Intern Med. 2011;22(2):147-52. https://doi.org/10.1016/j.ejim.2010.10.006.

2. Baron JH. Sailors' scurvy before and after James Lind-a reassessment. Nutr Rev. 2009;67(6):315-32. https://doi.org/10.1111/j.1753-4887.2009.00205.x.

3. Lanska DJ. Vitamin A-deficiency eye disease among soldiers in the U.S. civil war: spectrum of clinical disease. Milit Med. 2015;180(7):774-9. https://doi. org/10.7205/MILMED-D-14-00642.

4. Dror DK, Allen LH. Vitamin E deficiency in developing countries. Food Nutr Bull. 2011;32(2):124-43. https://doi.org/10.1177/156482651103200206.

5. Moran DS, McClung JP, Kohen T, Lieberman HR. Vitamin D and physical performance. Sports Med. 2013;43(7):601-11. https://doi.org/10.1007/s40279013-0036-y.

6. Kennedy DO. B vitamins and the brain: mechanisms, dose and efficacy-a review. Nutrients. 2016;8(2):68. https://doi.org/10.3390/nu8020068.

7. Holick MF. Vitamin D deficiency. New Engl J Med. 2007;357(3):266-81. https://doi.org/10.1056/NEJMra070553.

8. Goltzman D. Functions of vitamin D in bone. Histochem Cell Biol. 2018; 149(4):305-12. https://doi.org/10.1007/s00418-018-1648-y.

9. Bikle DD. Vitamin D and bone. Curr Osteoporos Rep. 2012;10(2):151-9. https://doi.org/10.1007/s11914-012-0098-z. 
10. Farrokhyar F, Tabasinejad R, Dao D, Peterson D, Ayeni OR, Hadioonzadeh R, et al. Prevalence of vitamin $D$ inadequacy in athletes: a systematic review and meta-analysis. Sports Med. 2015;45(3):365-78. https://doi.org/10.1007/s4 0279-014-0267-6.

11. Gloth FM, Gundberg CM, Hollis BW, Haddad JG, Tobin JD. Vitamin D deficiency in homebound elderly persons. JAMA. 1995;274(21):1683-6. https://doi.org/10.1001/jama.1995.03530210037027.

12. Gordon CM, DePeter KC, Feldman HA, Grace E, Emans SJ. Prevalence of vitamin D deficiency among healthy adolescents. Arch Pediatr AdolescMed. 2004;158(6):531-7. https://doi.org/10.1001/archpedi.158.6.531.

13. Dao D, Sodhi S, Tabasinejad R, Peterson D, Ayeni OR, Bhandari M, et al. Serum 25-hydroxyvitamin D levelsand stress fractures in military personnel. Am J Sports Med. 2014;43(8):2064-72. https://doi.org/10.1177/0363546514 555971

14. Farina EK, Taylor JC, Means GE, Murphy NE, Pasiakos SM, Lieberman HR, McClung JP (2017) Effects of deployment on diet quality and nutritional status markers of elite U.S. Army special operations forces soldiers. Nutr J 16:41.

15. O'Leary F, Samman S. Vitamin $B_{12}$ in health and disease. Nutrients. 2010;2(3): 299-316. https://doi.org/10.3390/nu2030299.

16. Ryan-Harshman M, Aldoori W. Vitamin B12 and health. Can Fam Physician. 2008:54:536541.

17. Shipton MJ, Thachil J. Vitamin B12 deficiency-a 21st century perspective. Clin Med. 2015;15(2):145-50. https://doi.org/10.7861/clinmedicine.15-2-145.

18. Allen LH. How common is vitamin B-12 deficiency? Am J Clin Nutr. 2009; 89(suppl):693S-6S. https://doi.org/10.3945/ajcn.2008.26947A.

19. Pawlak R, Parrott SJ, Raj S, Cullum-Dugan D, Lucus D. How prevalent is vitamin B12 deficiency among vegetarians? Nutr Rev. 2014;71(2):110-7.

20. Knapik JJ, Jean RT, Austin KG, Steelman RA, Gannon J, Farina EK, et al. Temporal trends in dietary supplement prescriptions of United States military service members suggest a decrease in pyridoxine and increase in vitamin D supplements from 2005 to 2013. Nutr Res. 2016;36(10):1140-52. https://doi.org/10.1016/j.nutres.2016.09.001.

21. Pfeiffer CM, Lacher DA, Schleicher RL, Johnson CL, Yetley EA. Challenger and lessions learned in generating and interperting NHANES nutritional biomarker data. Adv Nutr. 2017;8(2):290-307. https://doi.org/10.3945/an.116. 014076.

22. Dean AG, Sullivan KM, Soe MM (2014) Open source epidemiology statistics for public health. https://www.openepi.com/v37/Menu/OE Menu.htm. Accessed 3 January - 4 march 2019.

23. Knapik JJ, Jean RT, Austin KG, Steelman RA, Farina EK, Lieberman HR. Demographic factors associated with dietary supplement prescriptions filled by United States military service members 2005-2013. BMC Complement Altern Med. 2017;17:84

24. Institute of Medicine. Dietary reference intakes for calcium, potassium, magnesium, vitamin D and Flouide. Washington: National Academy Press; 1997.

25. Moore C, Murphy MM, Keast DA, Holick MF. Vitamin D intake in the United States. J Am Dietet Ass. 2004;104(6):980-3. https://doi.org/10.1016/j.jada.2 004.03.028.

26. Calvo MS, Whiting SJ. Prevalence of vitamin D insufficiency in Canada and the United States: importance to health status and efficacy of current food fortification and dietary supplement use. Nutr Rev. 2003;61(3):107-13. https://doi.org/10.1301/nr.2003.marr.107-113.

27. Brody JE (2010) What do you lack? Probably Vitamin D New York Times July 26.

28. Nagourney E. Nutrition: shortage of vitamin D may weaken the elderly. New York Times. 2007:1:12.

29. Johnson TD. Guarding against the dangers of vitamin D deficiency. Life Extension Mag. 2007:15-21.

30. Life J (2009) Vitamin D deficiency soars in the US study says. https://www. scientificamerican.com/article/vitamin-d-deficiency-united-states/. Accessed 5 August 2014.

31. Bordelon P, Ghetu MV, Langan R. Recognition and management of vitamin D deficiency. Am Fam Physician. 2009;80(8):841-6.

32. Edlich RF, Mason SS, Reddig JS, Gubler K, Long WB. Revolutionary advances in the diagnosis of vitamin D deficiency. J Environ Pathol Toxicol Oncol. 2010; 29(2):85-9. https://doi.org/10.1615/JEnvironPatholToxicolOncol.v29.i2.20.

33. Institute of Medicine. Dietary reference intakes for calcium and vitamin D. Washington: National Academies Press; 2011.

34. Cashman KD, Muldowney S, McNulty B, Nugent A, FtizGerald AP, Kiely M, et al. Vitamin D status of Irish adults: finding from the National Adult Nutrition Survey. Br J Nutr. 2013;109(7):1248-56. https://doi.org/10.1017/ S0007114512003212
35. Knapik JJ, Austin KG, Farina EK, Lieberman HR. Dietary supplement use in a large, representative sample of the United States armed forces. J Acad Nutr Diet. 2018;118(8):1370-88. https://doi.org/10.1016/j.jand.2018.03.024.

36. Dahlquist DT, Dieter BP, Koehle MS. Plausible ergogenic effects of vitamin D on athletic performance and recovery. J Int Soc Sports Nutr. 2015;12(1):33. https://doi.org/10.1186/s12970-015-0093-8.

37. LeBlanc PN, Johnson JD, Ballatore A, Hillier T. Over-the-counter and compound vitamin D: is potency what we expect? JAMA Intern Med. 2013; 173(7):585-6. https://doi.org/10.1001/jamainternmed.2013.3812.

38. National Research Council. Recommended dietary allowance. 10th ed. Washington: National Academy Press; 1989.

39. Institute of Medicine. Dietary reference intakes for vitamin a, vitamin $\mathrm{K}$, arsenic, boron, chromium, copper, iodine, Iron, manganese, molybdenum, Nikel, silicon, vanadium, and zinc. Washington: National Academies Press; 2000.

40. Penniston $\mathrm{KL}$, Tanumihardjo SA. Vitamin a in dietary supplements and fortifie foods: too much of a good thing? J Am Dietet Ass. 2003;103(9): 1185-7. https://doi.org/10.1016/S0002-8223(03)00978-7.

41. Anderson JJB. Oversupplementation of vitamin a and osteoporotic fractures in the elderly: to supplement or not to supplement with vitamin a. J Bone Mineral Res. 2002;17(8):1359-62. https://doi.org/10.1359/jbmr.2002.17.8.1359.

42. Pfeiffer $\mathrm{CM}$, Johnson $\mathrm{CL}$, Jain RB, Yetley EA, Picciano MF, Radner Jl, et al. Trends in blood folate and vitamin B-12 concentrations in the United States, 1988-2004. Am J Clin Nutr. 2007;86(3):718-27. https://doi.org/10.1093/ajcn/ 86.3.718.

43. Vaccaro JA, Huffman FG. Race/ethicity- gender- and age-specific differences in micronutrient intake of US adults with and without diabetes. Int J Food Sci Nutr. 2013;64(2):175-84. https://doi.org/10.3109/09637486.2012.710894.

44. Blumberg JB, Frei B, Fulgoni VL, Weaver CM, Zeisel SH. Contribution of dietary supplements to nutritional adequacy in race/ethnic population subgroups in the United States. Nutrients. 2017;9(12):1295. https://doi.org/1 0.3390/nu9121295.

45. Bailey RL, Dodd KW, Gahche JJ, Dwyer JT, McDowell MA, Yetley EA, et al. Total folate and folic acid intake from foods and dietary supplements in the United States: 2003-2006. Am J Clin Nutr. 2010;91(1):231-7. https://doi.org/1 0.3945/ajcn.2009.28427.

46. Armed Forces Health Surveillance Branch. Ambulatory visits, active component, U.S. armed forces, 2017. MSMR. 2018;25(5):17-23.

47. Owens GM. Gender differences in health care expenditures, resource utilization, and quality of care. J Manag Care Pharm. 2008;14(3):S2-6.

48. Friberg IO, Krantz G, Maatta S, Jarbrink K. Sex differences in health care consumption in Sweden: a register-based cosss-sectional study. Scand J Pub Health. 2016;44(3):264-73. https://doi.org/10.1177/1403494815618843.

49. Blumberg JB, Frei B, Fulgoni VL, Weaver CM, Zeisel SH. Contribution of dietary supplements to nutritional adequacy in various adult age groups. Nutrients. 2017;9(12):1325. https://doi.org/10.3390/nu9121325.

50. Fryar CD, Hughes JP, Herrick KA, Ahluwalia N. Fast food consumption among adults in the United States, 2013-2016. NCHS Data Brief. 2018;322:1-8.

51. Poti JM, Mendez MA, Ng SW, Popkin BM. Highly processed and ready-to-eat packaged foodand beverage purchases differ by race/ethnicity among US households. J Nutr. 2016;146(9):1722-30. https://doi.org/10.3945/jn.116.230441.

52. Eicher-Miller HA, Fulgoni VL, Keast DR. Energy and nutrient intake from processed foods differ by sex, income status, and race/ethnicity of US adults. J Acad Nutr Diet. 2015;115(6):907-18. https://doi.org/10.1016/j.jand.2 014.11.004.

\section{Publisher's Note}

Springer Nature remains neutral with regard to jurisdictional claims in published maps and institutional affiliations. 